\title{
Variability and Intra-Specific Classification of Lima Bean (Phaseolus lunatus L.) from Timor Island based on Morphological Characters
}

\author{
Emilia Juliyanti Bria ${ }^{1 *}$, E. Suharyanto ${ }^{2}$ Purnomo $^{3}$ \\ 1) Program Study of Biology, Faculty of Agriculture, University of Timor \\ 2) Laboratory of Plant Structure and Development, Faculty of Biology, Universitas Gadjah Mada \\ 3) Laboratory of Plant Systematic, Faculty of Biology, Universitas Gadjah Mada \\ *Corresponding author. Tel.: +62812 3628 0422. Email address: emiliajuliyanti@gmail.com
}

\section{Keywords: \\ Phaseolus lunatus L. morphological variability phenetic relationship Timor Island}

\section{Article history:}

Submitted 11/01/2019

Revised 15/05/2019

Accepted 15/05/2019

\begin{abstract}
Lima bean (Phaseolus lunatus L.) is a species of beans which originating from the regions of Central America and Andes Mountains. Lima bean in Timor Island is underutilized although these plant growth there and have many variations. This study aims to determine the diversity of lima beans on Timor Island based on morphological characters. Samples were collected by survey methods from three districts on the island of Timor. Morphological traits related to the vegetative and flowering stages and mature seeds morphology were scored using the International Plant Genetic Resources Institute lima bean descriptors with a soft modification. The similarity index is calculated using the General Similarity Coefficient Gower formula. The dendrogram is generated from cluster analysis using the Unweighted Pair Group Methods using Arithmetic Average (UPGMA) method. Furthermore, Principal Component Analysis (PCA) was used to determine the role of each morphological character used. The dendrogram shows that 23 collected accessions are divided into two main clusters with a $57 \%$ similarity index. The two clusters are distinguished based on the presence or absence of secondary colors and secondary patterns in the seed organs. Then, each main cluster is divided into two subclasses based on the character of the pigmentation stem, the length of the terminal leaflets, flower color, and seed type.
\end{abstract}

\section{INTRODUCTION}

Phaseolus lunatus that known as lima bean is one of the important seeds that belonging to the family Fabaceae. This plant is one of the important legume plants which contain essential acids. It is one of the underutilized legume groups, but its nutritional content can be used as an alternative to overcome the malnutrition problem for people in developing countries (Kyeremateng, 2015; Arora, 2014). This plant have many vernacular names based on dispersed in many country, such as butter bean, sieva bean, madagascar bean (En), Haricot de lima, pois du Cap, pois souche, pois savon (Fr), Feijao de lima, feijao favona, feijao espandinho (Portugal), Mfiwi (Sw), sibatse simaron, patáni, rabache (Philipina), thua rachamat (Thailand); dâu ngu (Vietnam). In Indonesia, lima bean has a lot of local names, such as kacang mas, roay (Sunda), kara, kratok (Java), kratok, gribig (Madura), saru (Minahasa), merab bean (Pontianak), and koto, arbila (Timor) (Baudoin, 1989).

Lima bean has a good adaptation capability in the tropics especially in less fertile, high humidity soils, dry climate and wet soil PH (Yaguiu, 2003; Kole, 2014). The geographic distribution of lima bean is widespread from arid climate region to high humidity areas. Lima bean is living in lowlands to highlands $(50-2750 \mathrm{~m}$ asl) approximately (Bauodin et al., 2004). The distribution area of lima bean in the world is Mexico, Guatemala, Ecuador, Peru, Colombia, Madagascar, Spain, parts of Africa, spread to Asian regions, especially the Philippines, Indonesia (Java), Myanmar (Burma) and Mauritius. In the late 19th century, this plant was brought and cultivated in Europe and Asia, initiated from the Philippines to Myanmar, then to Java Island. Lima bean began to be cultivated in the Minahasa region 
and around Java. In addition to the area, in Bali and East Nusa Tenggara, these seeds are consumed by mixing with staple foods, namely rice, corn and cassava (Baudoin, 2006; Smykal et al., 2015).

Lima bean is the annual to perennial climbing plants which have a hood shape of standard flowers and twinning keels. The wild lima bean species show uncertain climbing growth habits, with prolonged flowering periods and large pod production (Zoro Bi et al., 2003). This type of pole usually shows a twining feature with a large and perennial rootstock. There is also a form of annual shrub developed in cultivation (Santos et al., 2008). The seeds have a rich variant, consist of the shape, size, color, and eye appearance. Sometimes the color of pale green flowers is purple (Beyra \& Artiles, 2004) and its size, is smaller than common bean (Phaseolus vulgaris).

Botanical varieties of lima bean consist of var. silvester for the wild material and var. lunatus for the domesticated one. Furthermore, there are three major gene pools: One Andean gene pool (A) and two Mesoamerican gene pools (MI and MII); with one domestication event in each of them: 1) for A, the midaltitude western valleys between Ecuador and Peru in South America; 2) the central eastern region from Mexico for MI; and 3) the region located between Guatemala and Costa Rica for MII. Within the var. lunatus, Baudet (1977) indicated the existence of three cultigroups: 1) Sieva, with medium -sized and flat seeds; 2) Potato, with small globular seeds; and 3) Big lima, with large flat seeds. Big Lima represents the A gene pool, while Sieva and Potato represent the MI and MII gene pools (Silva, et al., 2017).

In Indonesia, varieties of lima bean consist of four groups. They are 1) java bean, have red seed and contains HCN; 2) red Rangoon/Burma bean, have small red seed with white spot and not contain $\mathrm{HCN}$; 3) white Rangoon/Burma bean, have small white seed and not contain HCN; and 4) kratok/ lima bean, white flat seed and not contain HCN (PROSEA, 1993). Besides that, Purwanti \& Prihanta (2017) divide lima bean from East Java into two main cultigroups based on classification according to (Baudet 1977). There are 1) medium-large size cultigroup (Sieva-Big lima group) and 2) smallmedium sized seed (Potato-sieve group).

Lima bean in Timor Island has many seed shapes and colors. But the information and utilization of this plant in East Nusa Tenggara is very limited (Koten et al., 2013; Mundita, 2013). This greatly affects the conservation and breeding efforts of a plant. Plant breeding can be started from the selection of genetic diversity in a crop species, selecting the best variety for cross mains, to create cultivars that have high production, disease resistance, with vigorous growth (Purnomo et al., 2015). Therefore, the collection, evaluation and characterization and to show their diversity in genetic, morphological, or physiological is necessary. Morphological characters are important basic data in expressing genetic diversity. Besides that, the morphological character may be used to identify germplasm collections duplication, genetic diversity estimation study, and correlational study between morphology and other important agronomical traits (Purwanti \& Prihanta; 2017). The objective of this research was to determine the diversity of lima bean based on morphological characters. The study is important to identify the range of variation and morphological similarity among accession using cluster analysis. The result is useful for the identification of characters selection on lima bean cultivation and conservation.

\section{MATERIALS AND METHODS}

\section{Materials}

This study was conducted in March 2016 to October 2016. Twenty-three sample accession was obtained from 19 villages in Kupang District, Timor Tengah Selatan District, and Timor Tengah Utara District (Table 1). The sampling locations have altitude ranging from $235 \mathrm{~m}$ asl $-1250 \mathrm{~m}$ asl.

\section{Methods}

Sample or accession collection was conducted based on observation and plant survey method. A sample of lima beans are stem, leaves, flowers, fruits, and seeds. The morphological data were taken in the field directly and make their specimen vouchers and take picture for determination. Morphological characterization is done by coding and scoring based on Biodiversity International (International Board for Plant Genetic Resources, Rome, Italy; IBPGR, 1982) with soft modification (Table 2).

Morphological data were analyzed by description for characterization to construct identification key. Similarity index was counted by Gower General Similarity Coefficient formula based on morphological characters data. Cluster analysis was conducted by UPGMA (Unweighted Pair Group Methods using Arithmetic averages) analysis to create a dendrogram with MVSP (Multivariate Statistical Program) v.3.1 software. Principal component analysis (PCA) was also performed to define the role of each morphological character in the grouping of accessions. 
Table 1. Plant materials.

\begin{tabular}{|c|c|c|c|c|}
\hline No. & $\begin{array}{l}\text { Accession } \\
\text { code }\end{array}$ & Location (Village/District) & Local name & Morphological Characteristics \\
\hline 1 & TU1 & $\begin{array}{l}\text { Oerinbesi/Timor Tengah } \\
\text { Utara }\end{array}$ & Koto fui & Flower purple; seed red purplis, plain, , small type \\
\hline 2 & TU2 & $\begin{array}{l}\text { Manusasi, Timor Tengah } \\
\text { Utara }\end{array}$ & Koto & $\begin{array}{l}\text { Flower purple, seed brown with stripe pattern } \\
\text { and white second color, medium-big type }\end{array}$ \\
\hline 3 & TU3 & Eban, Timor Tengah Utara & Koto & $\begin{array}{l}\text { Flower white, seed maroon without pattern and } \\
\text { second color, small-medium type }\end{array}$ \\
\hline 4 & TU4 & Benpasi, Timor Tengah Utara & Koto fui & $\begin{array}{l}\text { Flower purple, seed black without pattern and } \\
\text { second color, medium-big type }\end{array}$ \\
\hline 5 & TU5 & Lapeom, Timor Tengah Utara & Koto & $\begin{array}{l}\text { Flower purple, seed white with spot pattern and } \\
\text { red second color, small-medium type }\end{array}$ \\
\hline 6 & TU6 & $\begin{array}{l}\text { Fafinesu, Timor Tengah } \\
\text { Utara }\end{array}$ & Koto molo & $\begin{array}{l}\text { Flower white, seed yellow without pattern and } \\
\text { second color, big type }\end{array}$ \\
\hline 7 & TU7 & $\begin{array}{l}\text { Fafinesu A, Timor Tengah } \\
\text { Utara }\end{array}$ & Koto & $\begin{array}{l}\text { Flower purple, seed purple-reddish without pat- } \\
\text { tern and second color, small-medium type }\end{array}$ \\
\hline 8 & TS1 & $\begin{array}{l}\text { Maunum, Timor Tengah Se- } \\
\text { latan }\end{array}$ & Koto fui & $\begin{array}{l}\text { Purple Flowe purpler, seed purple-redish without } \\
\text { pattern and second color, small-medium type }\end{array}$ \\
\hline 9 & TS2 & Supul, Timor Tengah Selatan & Koto bibi & $\begin{array}{l}\text { Flower white, seed white, maroon second color, } \\
\text { big type }\end{array}$ \\
\hline 10 & TS3 & $\begin{array}{l}\text { Nobi-Nobi, Timor Tengah } \\
\text { Selatan }\end{array}$ & Kot'molo & $\begin{array}{l}\text { White Flower white, seed yellow without pattern } \\
\text { and second color, medium-big type }\end{array}$ \\
\hline 11 & TS4 & $\begin{array}{l}\text { Mnelalete, Timor Tengah } \\
\text { Selatan }\end{array}$ & Koto & $\begin{array}{l}\text { Flower purple, seed black without pattern and } \\
\text { second color, small-medium type }\end{array}$ \\
\hline 12 & TS5 & $\begin{array}{l}\text { Binaus, Timor Tengah Se- } \\
\text { latan }\end{array}$ & Koto fui & $\begin{array}{l}\text { Flower white, seed purple-reddish without pat- } \\
\text { tern and second color, small-medium type }\end{array}$ \\
\hline 13 & TS6 & $\begin{array}{l}\text { Binaus, Timor Tengah Se- } \\
\text { latan }\end{array}$ & Koto fui & $\begin{array}{l}\text { Flower purple, seed black without pattern and } \\
\text { second color, medium-big type }\end{array}$ \\
\hline 14 & TS7 & $\begin{array}{l}\text { Binaus, Timor Tengah Se- } \\
\text { latan }\end{array}$ & Koto & $\begin{array}{l}\text { Purple Flower purple, seed brown without pat- } \\
\text { tern and second color, medium-big type }\end{array}$ \\
\hline 15 & TS8 & $\begin{array}{l}\text { Binaus, Timor Tengah Se- } \\
\text { latan }\end{array}$ & Kot'bibi & $\begin{array}{l}\text { White Flower white, seed white with spot pattern } \\
\text { and maroon second color, medium-big type }\end{array}$ \\
\hline 16 & TS9 & $\begin{array}{l}\text { Benlutu, Timor Tengah Se- } \\
\text { latan }\end{array}$ & Koto & $\begin{array}{l}\text { Flower purple, black seed without pattern and } \\
\text { second color, medium-big type }\end{array}$ \\
\hline 17 & TS10 & $\begin{array}{l}\text { Tuppan, Timor Tengah Se- } \\
\text { latan }\end{array}$ & Koto & $\begin{array}{l}\text { White Flower white, seed purple-reddish without } \\
\text { pattern and second color, medium-big type }\end{array}$ \\
\hline 18 & KP1 & Oben, Kupang & Arbila & $\begin{array}{l}\text { Flower purple, seed white with dot pattern and } \\
\text { maroon second color, medium-big type }\end{array}$ \\
\hline 19 & KP2 & Teunbaun, Kupang & Arbila & $\begin{array}{l}\text { Purple Flower purple, seed black with dot/line } \\
\text { pattern and white second color, medium-big type }\end{array}$ \\
\hline 20 & KP3 & Besmarak, Kupang & Arbila & $\begin{array}{l}\text { White Flower white, seed white with dot/line } \\
\text { pattern and second maroon color, medium-big } \\
\text { type }\end{array}$ \\
\hline 21 & KP4 & Oeletsala, Kupang & Arbila & $\begin{array}{l}\text { White Flower white, seed white with dot pattern } \\
\text { and red second color, medium-big type }\end{array}$ \\
\hline 22 & KP5 & Takari, Kupang & Arbila & $\begin{array}{l}\text { Flower purple, seed white with dot pattern and } \\
\text { red second color, medium-big type }\end{array}$ \\
\hline 23 & KP6 & Camplong II & Arbila hutan & $\begin{array}{l}\text { White Flower white, seed black without pattern } \\
\text { and second color, small-medium type }\end{array}$ \\
\hline
\end{tabular}

\section{RESULTS AND DISCUSSION}

\section{Morphological variability}

Based on the observation, morphology variation of lima bean are very striking on leaf, fruit flowers and seeds. Lima bean has oval to round of leaf shapes (Figure 1. B1 \& B2). It is determined by the ratio of the length and width of the leaf terminals. In the flower organ, the variation appears in the flag and wing part. The flag has a two-color variation, green and green-purple. The colors of the wing part have two variations, white and purple (Figure 1. C1 \& C2).

In part of fruit organs variation appears in pods curve, there are straight and slightly curved pod shape (Fig. 1-D). Seed variation appears on their 
Table 2. Characters and Character states of morphological character of lima bean based on IBPGRI (1982) with modifications.

\begin{tabular}{|c|c|c|c|}
\hline No. & Characters & Code & Character state \\
\hline 1 & Growth habit & $\mathrm{H}$ & (1) deterrminate; (2) indeterminate semiclimbing (3) indeterminate climbing \\
\hline 2 & $\begin{array}{l}\text { Differences of main stem } \\
\text { and branches }\end{array}$ & PWBTM & (1) yes; (2) no \\
\hline 3 & Pigmentation of main stem & PBU & (0) no; (3) on nodus; (5) widespread \\
\hline 4 & Leaflet lenght & PND & (3) $5-7 \mathrm{~cm}$; (5) $9-11 \mathrm{~cm}$; (7) $13-15 \mathrm{~cm}$ \\
\hline 5 & Leaflet shape & BD & (1) bulat $<1,5$; (3) oval 1,5-2; (5) oval-lanset 2-3; (7) lanset 3-6 \\
\hline 6 & Margin main leaf & KTLD & (0) no; (3) limited ; (5) widespread \\
\hline 7 & Leaf color & WD & (3) light green; (5) dark green \\
\hline 8 & Color of flower keel & WLA & (1) green; (2) pink to purple \\
\hline 9 & Color of flower standard & WSA & (1) white-greenish; (3) purple-greenish \\
\hline 10 & Color of flower wings & WSB & (1) white; (3) light pink; (5) lilac \\
\hline 11 & Wing opening & PS & $\begin{array}{l}\text { (0) parallel wings-closed; (3) intermediate opening; (5) wings widely } \\
\text { diverging }\end{array}$ \\
\hline 12 & Raceme position & PoPB & (3) within foliage; (5) intermediate; (7) emerging from leaf canopy \\
\hline 13 & Pod beak shape & BPP & 1) short beak; 2) medium length beak; 3) long beak; 4) thick beak \\
\hline 14 & $\begin{array}{l}\text { Position of pod bearing } \\
\text { racemes }\end{array}$ & PPB & $\begin{array}{l}\text { (1) Mainly concentrated at the base; (2) Mainly concentrated in the } \\
\text { middle; (3) Mainly concentrated at the top; (4) Evenly distributed } \\
\text { throughout the plant; (5) Variably distributed }\end{array}$ \\
\hline 15 & $\begin{array}{l}\text { Orientation of pod bearing } \\
\text { racemes }\end{array}$ & OPB & (1) perpendicular; (2) linear \\
\hline 16 & Cross section shape of pods & PMP & (1) flat; (2) round-cone; (3) ellipse; (4) number 8 shape \\
\hline 17 & Pod curvature & LP & (1) straight; (2) slightly curved; (3) curved \\
\hline 18 & Distribution pod on stem & DPB & $\begin{array}{l}\text { (1) variably distributed; (2) mainly concentrated at base ; (3) mainly } \\
\text { concentrated at the top }\end{array}$ \\
\hline 19 & Number seed per pod & JBI & (1) $1-2 ;(2) 3-4 ;(3)>5$ \\
\hline 20 & Seed shape & BBI & (1) round; (2) oval-cuboid; (3) kidney shape \\
\hline 21 & Seed primer color & WDBI & $\begin{array}{l}\text { (1) white; (2) gray; (3) yellow; (4) brown ; (5) maroon; (6) purple- } \\
\text { reddish; (7) black }\end{array}$ \\
\hline 22 & Seed second color & WKBI & $\begin{array}{l}\text { (0) no color; (1) white; (2) light brown/orange; (3) dark brown; (4) } \\
\text { red; (5) purple-reddish }\end{array}$ \\
\hline 23 & Second pattern color & PWKBI & 0) no pattern; (1) line; (2) specks; (3) blotches; (4) mixture \\
\hline 24 & Seed coat pattern & PBWKBI & $\begin{array}{l}\text { 0) no pattern; 1) pattern around eye only; 2)eye distinct with few } \\
\text { specks on body; 3) eye with blotches on body; 4) eye linked to other } \\
\text { parts of pattern, blotches and some specks may be present; 5) eye } \\
\text { not clear with soft specks }\end{array}$ \\
\hline 25 & Hilum shape & BHI & (1) round; (2) elips; (3) oval; (4) lancet \\
\hline 26 & Textur of testa & TT & (3) Smooth; (5) Moderately ridged; (7) Markedly ridged \\
\hline 27 & Seed length $(\mathrm{cm})$ & PBI & $(1)<1 ;(2) 1-1,5 ;(3)>1,5$ \\
\hline 28 & Seed width (cm) & LBI & $(1)<0,8 ;(2) 0,8-1,3 ;(3)>1,3$ \\
\hline 29 & Seed thickness $(\mathrm{cm})$ & TBI & $(1)<0,4 ;(2)>0,4$ \\
\hline
\end{tabular}

shape, size, color, and color pattern of the seed skin (Fig.2). Based on the size of the length, width, and thickness of the seeds the types of seed consist of four types of seeds. They are big type is the accession that belongs to the large seed group, the medium type that dominates in this grouping. It is divide into medium-big type and small-medium type and the last small type. This classification is made by Yaguiu et al. (2003) and Asante et al. (2008), that grouping seeds into five types of seeds based on seed size (length, width).

The color of seeds and the color pattern of lima seeds showed a very high variation. In his research, the color that dominates is a brownishyellow color and the second color is dark brown.
The results of this study showed that lima seed shells have a primer color of seeds and a second color that forms a certain pattern. The primer color of the seeds varies widely are white, yellow, brown, maroon, purple-reddish, and black. The second color on the body of the beans that form the color pattern are white, dark brown and red. Color patterns formed in the form of lines, dots, stains/ spots, and mixtures. Based on the morphological characteristics of the color and the color pattern that associated with the seed hilum areas in seed terminology, lima bean are grouped into three groups, (1) Plain seed (Fig. 2. A), seeds have one color only without any color patterns; (2) color with hilum seed (Fig. 2. B-1,2,3), seeds have hilum eye is 


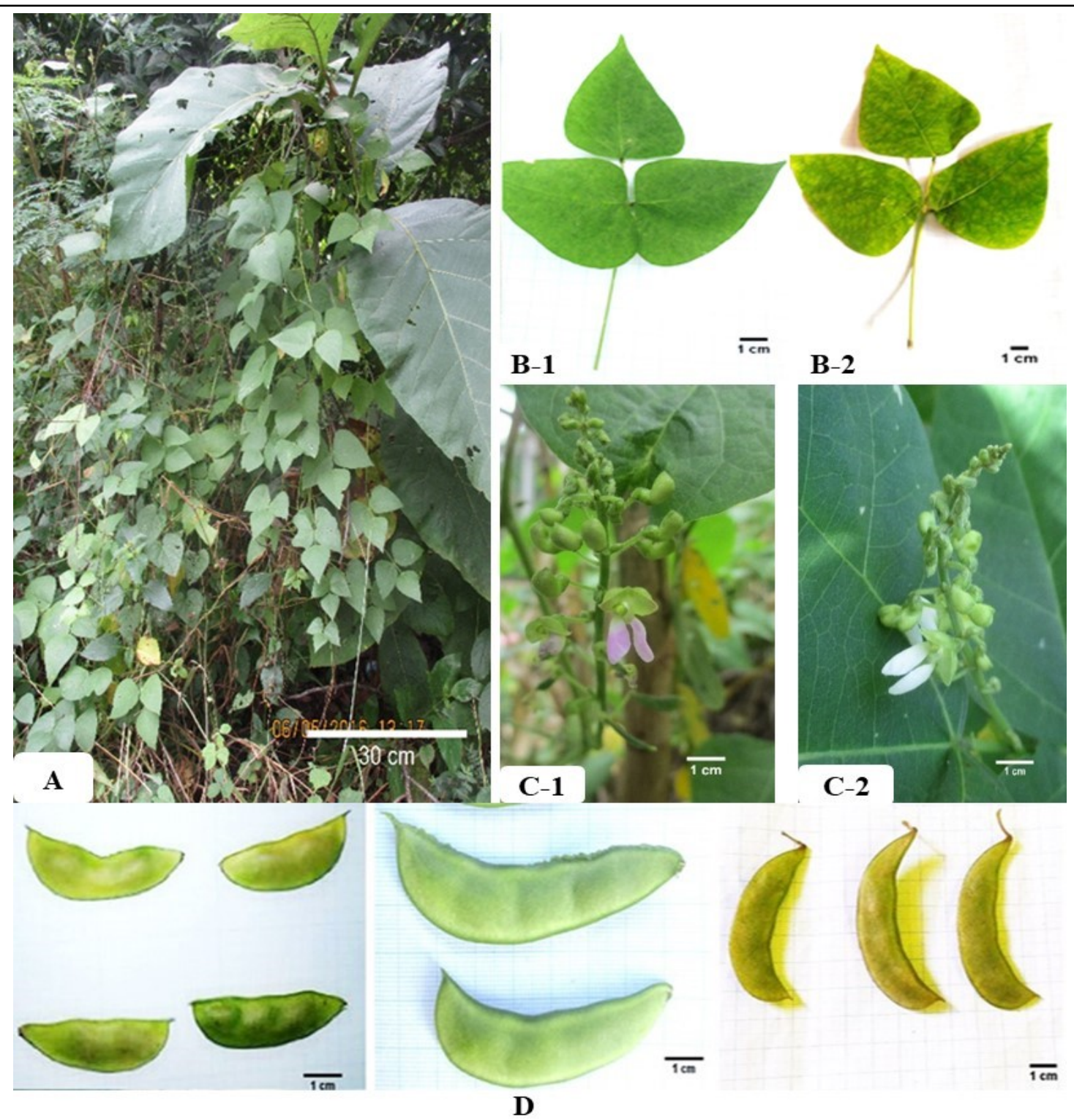

Figure 1. Morphological variation of lima bean. A. habit; B. Leaflet shape (B-1: oval, B-2: rounded); C. Color of flowers (C-1 purple flower, C-2 white flower); D. variation of pod shape.

associated with other pattern parts in the presence of spots and points on the seed body; (3) color with unclear hilum (Fig. 2. B-4,5), seeds have unclear eyes with spots on the seed body.

Cluster ana;ysis and principal component analysis

The combination of cluster analysis and principal component analysis has a purpose to result in a fundamental empirical role of morphological characters in grouping accession (Sari et al., 2016). The result of cluster analysis showed two main clusters on the dendrogram (Figure 3) with a similarity coefficient of $0.57-1$. Both of this cluster divided by secondary seed color. Cluster $\mathrm{A}$ has the secondary color of the seed and cluster B is devoid of the secondary color of the seed. Each group accession has a combination of morphological characters which is a marker of each accession group known as a distinguishing character that can be seen in Table 3.

Cluster A is divided into two subgroup groups A1 and A2. The distinguishing characteristics of these two subgroups are main stem pigmentation, wing opening, flower color, length and width of the seed. This character can be seen in Table 4. Martinez -Casstillo et al. (2004) classified this group as the cultivation group with papa-sieva seed (intermediate type). Cluster B is divided into subgroups B1 and B2. Distinguishing characters between these two subgroups are the terminal leaf terminals, flower color, and seed length. This character can be seen in Table 5.

Based on its origins, Debouck (1994) reveals that the white lima bean flowers are the Central American type and the purplish color is the Andes type. Furthermore, in relation to domestication, Martinez-Castillo et al. (2003) in his research revealed that the purple flowering variant is a type of cultivation similar to the wild type and the white 

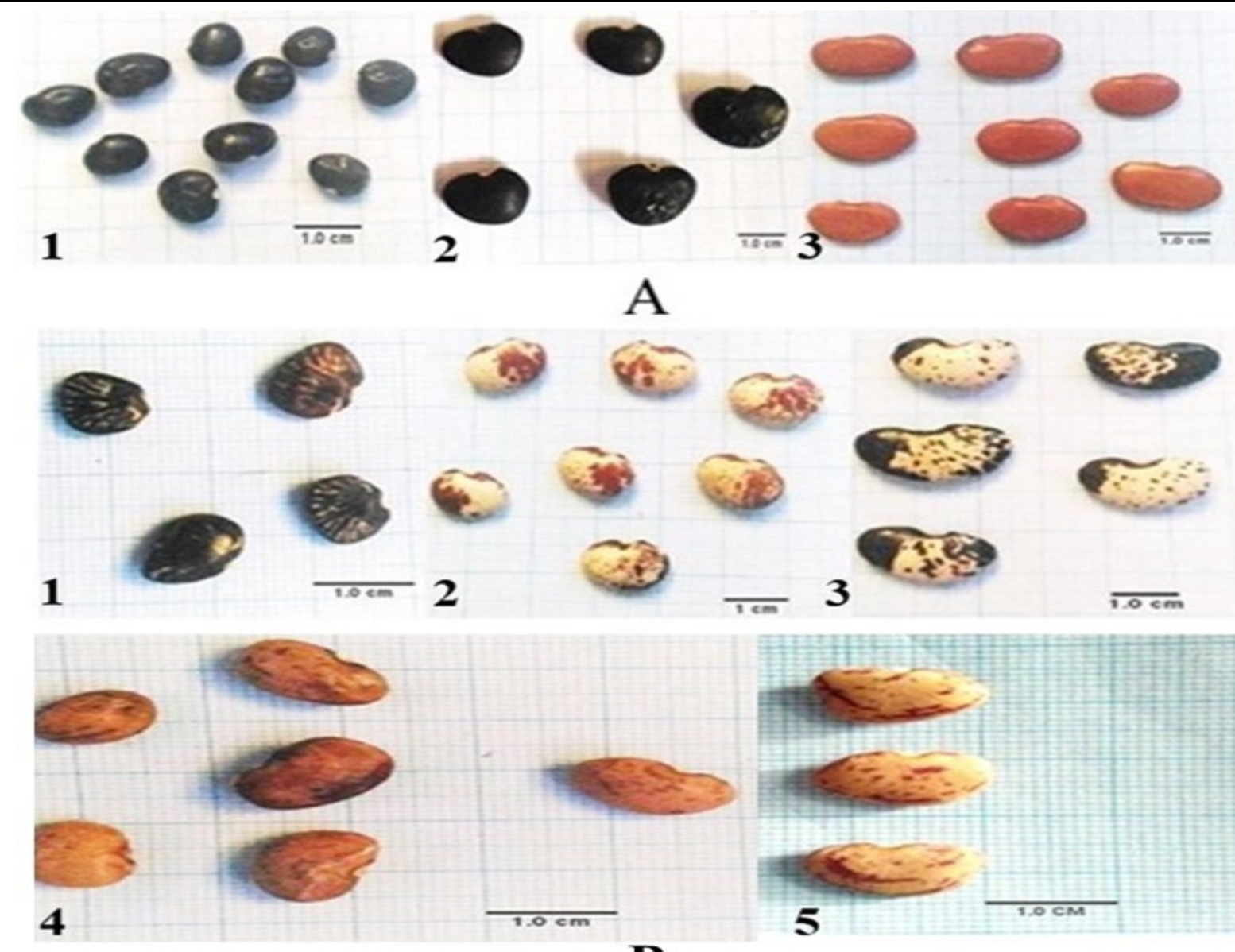

A

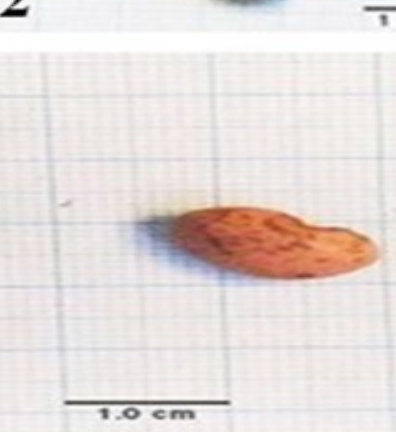

\section{B}

Figure 2. Variation of seed shape and color. (A) Seed without secondary color and pattern, (B) Seed with secondary color and pattern.

flowering is the type of cultivation. Kole (2014) stated that almost all cultivated crops of lima beans have white flower color also. This occurs because of the gene flow between wild-type germ plasma and cultivation type at some time ago. This statement can also be observed in the field. Generally, the white flowering is a variant of the most widely cultivated by local farmers.

Lioi (1994) states that lima bean has a high polymorphism especially on seed character. The size of lima bean seeds found is $0.9-2.5 \mathrm{~cm}$ long, 0.8 to $1.4 \mathrm{~cm}$ wide and 0.1 to $1 \mathrm{~cm}$ thick. Bauodin et al. (2004) revealed that local varieties of Central America are characterized by small seed groups. Local varieties of South America are characterized by large seed groups. It was stated by CSSA (2010) that the big seed varieties were domesticated in the Andean mountains, while the medium and small varieties originated from the western part of Central Mexico. However, both small seeds and large seeds are found in South America but not in the same habitat. In addition to seed size, lima bean has a variety of seed shape also. The form of seeds in this study was oval-cuboid and kidney form. This result was also presented by Martinez-Castillo et al. (2004) in collecting wild-type samples, local varieties and cultivated varieties in the Yucatan Peninsula, Mexico. The shape of round-elliptical seeds, grouped into papa groups and whose form of kidneys are grouped into sieva groups.

Yaguiu et al. (2003) argued that the basic color of lima beans is black, red, brown, white, yellow, and brownish brown generally. The pattern of color on the skin of the seeds, among others, specks, only on the hilum, dotted, and strike. Furthermore, MonteroRojas et al. (2013) in his study revealed the existence of other basic colors other than those proposed by Yaguiu et al. (2003) is the color purple. According to Gepts (2012), the color produced on the skin of the seed is a biochemical pigmentation process which is a flavonoid compound and includes anthocyanin. The production of pigments in stems, flowers, and fruits is a characteristic or wild type character of all species of cultivation. The pattern of the skin color of lima beans is closely related to the color of the stems, flowers, and fruits. However, the range of development of pigment and its expression on the skin of seed is larger than other organs. In this study, no color variation found in leaf organ like any other organ. This indicates that in leaf organs there is no proanthocyanin which has the ability to produce different colors. This is also stated by Onyilagha \& 


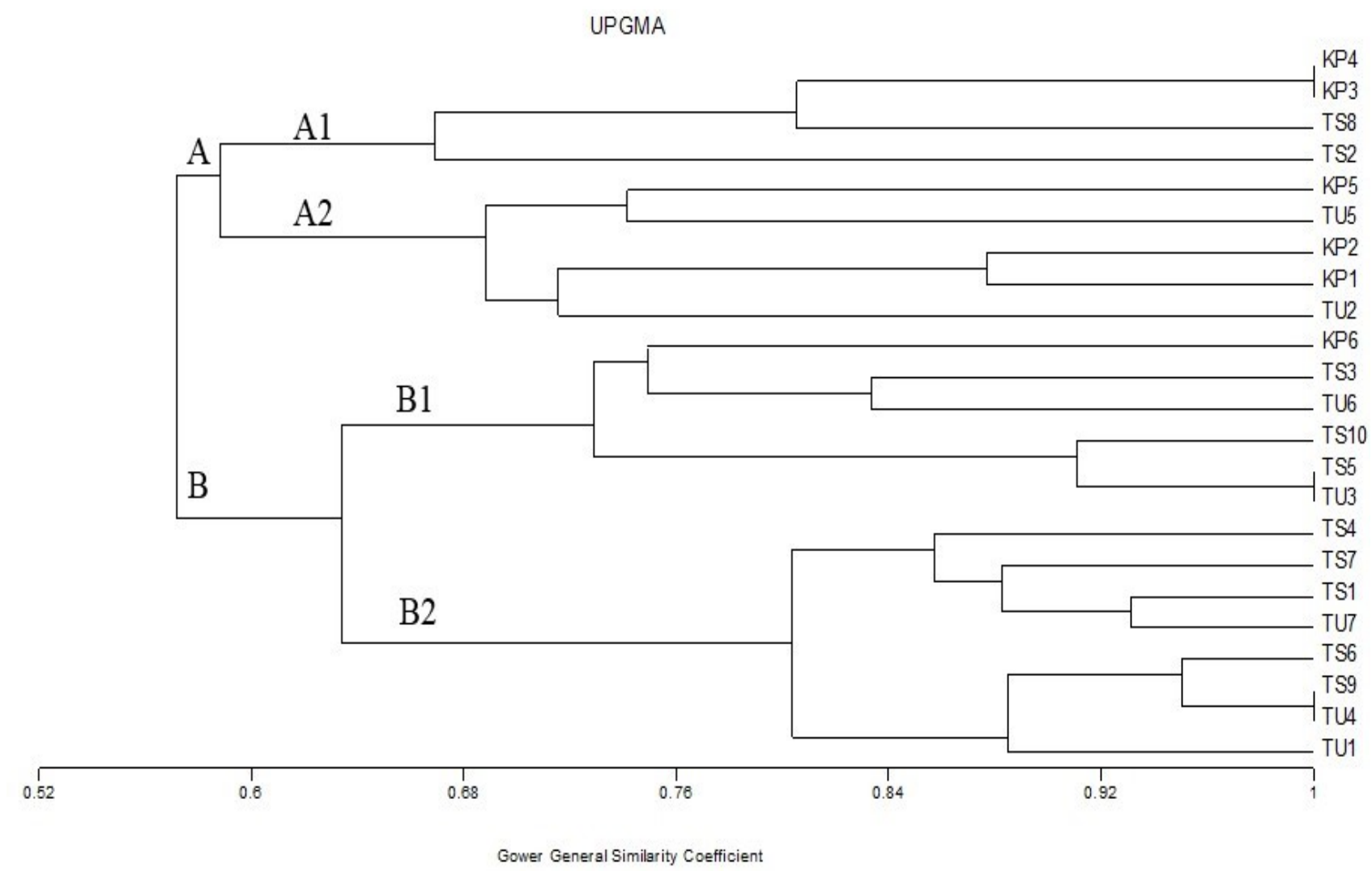

Figure 3. Dendrogram of 23 accession lima bean based on morphological characters used UPGMA analysis.

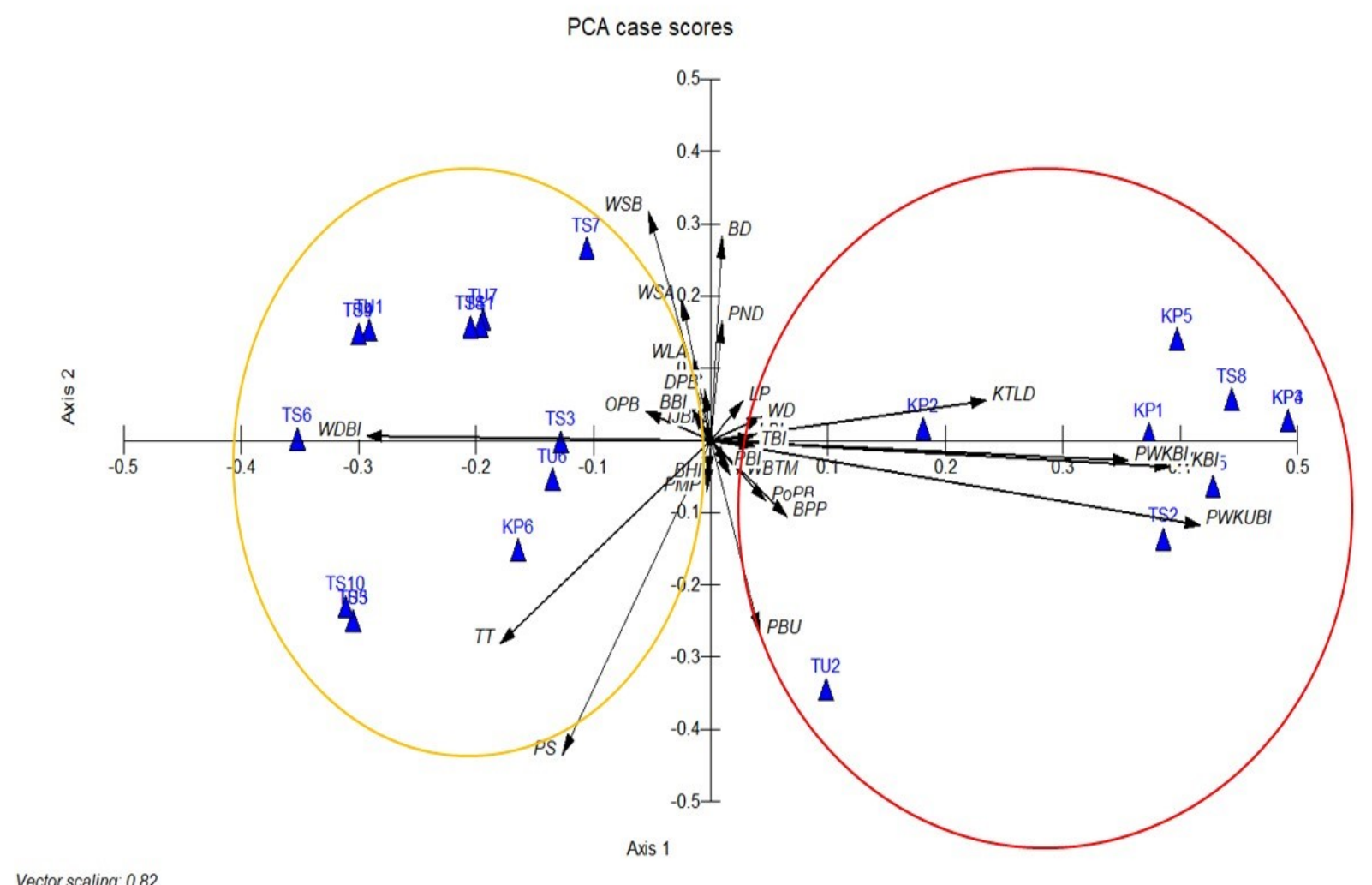

Figure 4. Diagram pattern of grouping accession and spread pattern of morphological characters of Phaseolus lunatus that define grouping accession. 
Table 3. Plain and color patterned seed distinguishing characters.

\begin{tabular}{llll}
\hline No. & Character & Group A & Group B \\
\hline 1 & Basic color of seeds & White, brown, black & Yellow, brown, purple, black \\
2 & Secondary color of seeds & White, red & None \\
3 & Second color pattern of seeds & lines, dots, stains / spots, and mixtures & None \\
4 & Seed coat color pattern & The eye is related to other parts of the & None \\
& & seed & \\
\hline
\end{tabular}

Table 4. Distinguishing Character of Subgroup A1 and A2.

\begin{tabular}{llll}
\hline No. & Character & Group A-1 & Group A-2 \\
\hline 1 & Stem pigmentation & None & Diverse \\
2 & Wing opening direction & Parallel & Parallel, intermediate \\
3 & Flower color & White & Purple \\
4 & Seed type & medium - big & small - medium \\
\hline
\end{tabular}

Table 5. Distinguishing character of subgroup B1 and B2.

\begin{tabular}{llll}
\hline No. & Character & Group B -1 & Group B - 2 \\
\hline 1 & Length of terminal leaflet & $5-7 \mathrm{~cm}$ & $9-11 \mathrm{~cm}$ \\
2 & Flower color & White & Purple \\
3 & Seed type & medium - big & small-big \\
\hline
\end{tabular}

Islam (2009) who studied the compounds of flavonoids and other phenol in Phaseolus group that is cultivated.

Gepts (2014) states that domestication of Phaseolus resulted in several changes, such as reduced seed dormancy, seed dispersion, photoperiod, and increased variety of pod and seed shape and color. This is also supported by research results MartinezCastillo et al. (2004), where the wild type has plant organs of varying color and shape is relatively small. In addition to this wild type, there are also intermediate types. The type still has the same characteristics as the wild type, but the variations are quite large and can be consumed. This is thought to be the result of gene flow between wild-type germ plasma and cultivation type at some time ago. It is also thought to be the result of a regressive mutation of a process seen in various tropical environments.

The distribution of the cluster on the dendrogram does not indicate a clear grouping between accessions by geographic area. This led to the grouping in this study not to be recognized formally as subspecies (Sari, et al.2016). Therefore, the morphological approach in this study supports the status of the research object as a species with high phenotype variability but is not divided into taxa that represent the formal category under the species based on the concept of the taxon. The role of each character in forming clusters on cluster analysis can be seen in the main component analysis (Figure 4).

The results of the main component analysis in the two-dimensional plot are not only showing the direction but also showing the small and large roles of each characters, which show as vectors with different length (Susandarini, et al., 2013). In this research, the eigenvalue value which is seen to show the important role in grouping is the eigenvalue which the magnitude is $\geq 0.3$. The accession group formed in the first axis consists of two groups A and B. The most important distinctive characters are the base color of the seed, the secondary color of the seed, the secondary color pattern and the color pattern of the two seed shells. Santos et al. (2010) suggest that it is this character first used to recognize the main gene pool and also to characterize the genetic diversity of the species.

Information obtained on morphological variations based on cluster analysis and major component analysis can be used to reveal the intraspecies classification of lima bean. The result of cluster analysis in the form of phenetic kinship between accessions is used as the basis for the classification of intraspecies based on open classification or informal classification (MartinezCastillo et al., 2004; Purnomo et al., 2015). Based on morphological characters which distinguishing lima bean accession, the informal classification of $P$. lunatus in Timor Island divided into two group accession, that is plain seed and pattern seed. Grouping of 23 accession P. lunatus in Timor Island shown in Table 6.

Based on the combination of morphological characters that distinguish $P$. lunatus in Timor Island, the parallel type of key for identification taxa of $P$. lunatus : 
1. a. have a secondary color on the seeds, and have a color pattern ............................... 2 b. does not have a secondary color and is not patterned on the seeds .......................... 3

2. a. there is no pigmentation in the stem, white flower, the type of sieve-big seed............. (color seed-white flower group)

b. diverse stem pigmentation, the color of the purple flower, the type of potato-sieve seed......................................A-2 (color seed-purple flower group)

3. a. length of leaflets terminal 5-7 cm, white flower color, type medium - big seed................ B-1 (plain seed-white flower group)

b. length of leaflets terminal $9-11 \mathrm{~cm}$, purple flower, type small - medium seed............. -2 (plain seed-purple flower group)

Table 6. Grouping of intra-specific 23 accessions $P$. lunatus.

\begin{tabular}{ll}
\hline Group & Accession code \\
\hline Plain seed lima bean & KP1, KP2, KP3, KP4, TS2, \\
& TS8, TU2, TU5 \\
Pattern seed lima & KP5, KP6, TS1, TS3, TS4, \\
bean & TS5, TS6, TS7, TS9, TS10, \\
& TU1, TU3, TU4, TU6, TU7 \\
\hline
\end{tabular}

\section{CONCLUSIONS}

Twenty-three accessions of lima beans ( $P$. lunatus) in Timor Island divided into two main clusters: (1) pattern seed and (2) plain seed lima bean group. Pattern seed group that have secondary and patterned colors are grouped into two subgroups based on stem pigmentation, flower color, and seed type. Plain seed group that does not have secondary and non-patterned colors in seeds are grouped into two subgroups based on terminal leaf length, flower color, and seed type. This classification could be informally classified into two cultivated varieties, namely poisonous and edible varieties.

\section{REFERENCES}

Arora, R.K., 2014, Diversity in Underutilized Plant Species - An Asia-Pacific Perspective. Bioversity International, New Delhi, India.

Asante, I.K., Offei, S.K., Addy, R., and Carson, A.G., 2008, Phenotypic and Seed Protein Analysis in 31 Lima Bean (Phaseolus lunatus) Accessions in Ghana, West African Journal of Applied Ecology, 12.

Baudoin, J.P., 1989, Sumber Daya Nabati Asia Tenggara 1, In: van der Maesen, L.J.G. \& Somaatmadja, S. (Editors.), Translator Danimihardja, S. Gramedia Pustaka Utama, Jakarta, pp 3, 66-70.
Baudoin, J.-P, O. Rocha, J. Degreef, A. Maquet and L. Guarino., 2004, Ecogeography, Demography, Diversity and Conservation of Phaseolus lunatus L. in the Central Valley of Costa Rica. Systematic and Ecogeographic Studies on Crop Genepools 12, International Plant Genetic Resources Institute, Rome, Italy.

Baudoin, J.P., 2006, Phaseolus lunatus L. In: brink,M. \& Belay, G. (Editors). Plant Resources of Tropical Africa (PROTA) 1: Cereals and Pulses/Cereals et legumes secs. (CD-Rom). PROTA, Wageningen, Netherlands, viewed in September 2015, from www.prota4u.org

Beyra A. and Artiles G.R., 2004, Revision Taxonomica De Los Generos Phaseolus Y Vigna (Leguminosae-Papilionoideae) En Cuba. Anales Del Jardin Botanico de Madrid. 61:135-154.

CSSA (Crop Science Society of America), 2010, 'Lima Beans Domesticated Twice', in Science daily 1 Sep. 2010, Viewed in August 2016, from http:www.sciencedaily. com/ releases/2010/08/100831222310.htm.

Debouck, D.G., 1994, Beans (Phaseolus spp.) Neglected Crops 1492 from a Different Perspective, Food and Agriculture Organization of The United Nations Rome, 26: 54 - 61.

Freytag, G.F \& Debouck, D.G., 2002, Taxonomy, Distribution and Ecology of the Genus Phaseolus (Leguminosae-Papilionoideae) in North America, Mexico and Cental America. Sida, Botanical Miscellary. Botanical Research Institute Texas. no. 23.

Gepts, P., 2012, Genetic Rosources of Phaseolus Beans: Their Maintenance, Domestication, Evolution and Utilization: Current Plant Science and Biotechnology in Agriculture. Springer science \& business media. 6, 152-155.

Gepts, P., 2014, Domestications of Phaseolus Beans and Their Importance for Conservation and Genetic Improvement, viewed in April 2015, from h t t p : / / w w w. i a s.c s i c.e s / grainlegumesmagazine/legum_perspect_2.pdf.

IBPGR (International Board for Plant Genetic Resources), 1982, Lima Bean Descriptors. IBPGR Secretariat. Rome.

Kole, E.T.M., 2014, Morphological and Genetic Characterisation of Some Lima Bean (Phaseolus lunatus L.) Cultivars and Their Nodulating Rhizobia. Thesis. Ghana

Koten, B.B., Soetrisno, R. D., Ngadiyono, N., dan Soewignyo, B., 2013, Penampilan Produksi Hijauan Hasil Tumpangsari Arbila (Phaseolus lunatus) Berinokulum Rhizobium dan Sorgum (Sorgbum bicolor) pada Jarak Tanam Arbila dan Jumlah Baris Sorgum. Sains Peternakan. 11 (1): 26-33. 
Kyeremateng, D.O., 2015, Determination of Compositional Characteristics, Functional Properties and Cluster Analysis of Lima Bean Accessions (Phaseolus Lunatus). Tesis. Kwame Nkrumah University of Science and Technology Kumasi, Ghana. Department of Food Science and Technology College of Science

Lioi, L., 1994, Morphotype Relationships in Lima Bean (Phaseolus lunatus L.) Deduced From Variation of The Evolutionary Marker Phaseolin. Genetic Resources and Crop Evolution. 41:81-85

Martinez-Castillo, J., Zizumbo-Vilarreal, D., PeralesRivera, H., and Colunga-Garciamarin, P., 2004, Intraspecific diversity and MorphoPhenological variation in Phaseolus lunatus L. from Yucatan Peninsula, Mexico. Economic Botany. 58(3):354-380.

Montero-Rojas, M., Ortiz, M., Beaver, J.S., and Siritunga, D., 2013, Genetic, Morphological and Cyanogen Content Evaluation of New Collection of Carribean Lima Bean (Phaseolus lunatus L.) Landraces. Genetical Resources Crop Evolution. 60:2241-2252.

Mundita, I.W., 2013, Pemetaan Pangan Lokal di Pulau Sabu-Raijua, Rote-Ndao, Lembata dan Daratan Timor Barat (Kabupaten Kupang dan TTS). Perkumpulan Pikul \& OXFAM. Kupang NTT. Pp. 6, 61 - 67.

Onyilagha, J.C. and Islam, S., 2009, Flavonoids and Other Polyphenols of The Cultivated Spesies of The Genus Phaseolus. Int. J. Agric. Biol. 11: $231-234$.

Purnomo, Daryono, B.S., and Sentori, M.B., 2015, Variability and Intraspecies Classification of Pumkin (Cucurbita moschata (Duch. ex Lam.) Duch. ex Poir.) Based on Morphological Characters. The 3rd International Conference on Biological Science. Knowledge life science. 2:286-293

Purwanti, E., Prihanta, W., 2017, Morphological Diversity and Germplasm Conservation Strategies of Phaseolus lunatus L in East Java. The $4^{\text {th }}$ International Conference the Community Development in ASEAN. 238 247.
Santos, J.O., Gomes, R.L.F., Lopes, A.C.A., Silva, S.C.C.C., Bastos, E.M., Costa, E.M.R., 2010, Genetic Divergence for Physical and Chemical Characters of Seeds in Lima Bean (Phaseolus lunatus L.) Annual Report of the Bean Improvement Cooperative. 53:178-179.

Sari, N., Purnomo, Daryono, B.S., Suryadiantina and Setyowati, M., 2016, Variation and Intraspecies Classification of Edible Canna (Canna indica L.) Based on Morphological Characters. AIP Conference Proceedings. 1744, 020041.

Silva, R. N. O., Burle, M. L., Padua, J. G., Lopes, Â. C. de Almeida Lopes3, Gomes, Regina, L. F. G., and Martínez-Castillo, J. Phenotypic diversity in lima bean landraces cultivated in Brazil, using the Ward-MLM strategy. Chilean Journal of Agricultural Research. 77(1): 35 - 40.

Smýkal, P., Coyne, C. J., Ambrose, M.J., Maxted, N., Schaefer,H., Blair,M.W., Berger, J., Greene,S.L., Nelson, M.N., Besharat, N., Vymyslický, T., Toker, C., Saxena,R.K., Roorkiwal, M., Pandey, M.K., Jinguo Hu, J., Li, Y.H., Wang, L.X., Guo, Y., Qiu, L.J., Redden, R.J. and Varshney, R.K., 2015, Legume Crops Phylogeny and Genetic Diversity for Science and Breeding. Critical Reviews in Plant Sciences. 34:1-3, 43-104.

Susandarini, R., Subandiah, S., Rugayah, Daryono, B.S., Nugroho, L. H., 2013, Assessment of Taxonomic Affinity of Indonesian Pummelo (Citrus Maxima (Burm.) Merr.) Based on Morphological Characters. American Journal of Agricultural and Biological Sciences. 8 (3):182-190

Yaguiu, A., Machado-Neto, N. B., and Cardoso, V. J. M., 2003, Grouping of Brazilian Accesses of Lima Beans (Phaseolus lunatus L.) According To SDS-PAGE Patterns and Morphological Characters. Maringa. 25(1):7-12.

Zoro Bi I. Maquet A., Baudoin JP., 2003, Population Genetic Structure of Wild Phaseolus lunatus (Fabaceae) with Special References to Population Sizes. American Journal of Botany. 90 (6):897-904. 